\title{
Erratum to: High quality RNA isolation from polyphenol-, polysaccharide- and protein-rich tissues of lentil (Lens culinaris)
}

\author{
Prasanta K. Dash
}

Published online: 20 September 2013

(c) The Author(s) 2013. This article is published with open access at Springerlink.com

Erratum to: 3 Biotech (2013) 3:109-114

DOI 10.1007/s13205-012-0075-3

In the article title of the original publication, the word "polyphenol" was incorrectly published as "ployphenol". The correct article title should read as follows.

"High quality RNA isolation from polyphenol-, polysaccharide- and protein-rich tissues of lentil (Lens culinaris)”

Open Access This article is distributed under the terms of the Creative Commons Attribution License which permits any use, distribution, and reproduction in any medium, provided the original author(s) and the source are credited.

The online version of the original article can be found under doi:10.1007/s13205-012-0075-3.

P. K. Dash ( $\square)$

NRC on Plant Biotechnology, IARI, LBS Building,

PUSA Campus, New Delhi 110012, India

e-mail: prasanta01@yahoo.com 